\title{
Actions of progesterone on depression-like behavior in a model of surgical menopause are mediated by $\mathrm{GABA}_{\mathrm{A}}$ receptors
}

\author{
Juan Francisco Rodríguez-Landa ${ }^{1,2}$ Oscar Jerónimo Olmos-Vázquez, ${ }^{3}$ Bruna Patrícia Dutra da Costa ${ }^{4,5}$ Monica \\ Lima-Maximino, ${ }^{6}$ Caio Maximino, ${ }^{5}$ Gabriel Guillén-Ruiz ${ }^{1,7}$
}

Laboratorio de Neurofarmacología, Instituto de Neuroetología, Universidad Veracruzana, Xalapa, Veracruz, México.

2 Facultad de Química Farmacéutica Biológica, Universidad Veracruzana, Xalapa, Veracruz, México.

3 Programa de Doctorado en Neuroetología, Instituto de Neuroetología, Universidad Veracruzana, Xalapa, Veracruz, México.

4 Programa de Doutorado em Biodiversidade e Biotecnologia da Amazônia Legal (BIONORTE), Marabá, Pará, Brazil.

5 Laboratório de Neurociências e Comportamento, Faculdade de Psicologia, Instituto de Estudos em Saúde e Biológicas, Universidade Federal do Sul e Sudeste do Pará. Marabá, Pará, Brazil.

- Laboratório de Neurofarmacologia e Biofísica, Departamento de Morfologia e Ciências Fisiológicas, Universidade do Estado do Pará, Campus VIII, Marabá, Pará, Brazil.

Cátedras Conacyt-Instituto de Neuroetología, Universidad Veracruzana, Xalapa, Veracruz, México.

Correspondence:

Juan Francisco Rodríguez Landa Laboratorio de Neurofarmacología Instituto de Neuroetología, Universidad Veracruzana.

Av. Dr. Luis Castelazo s/n.

Col. Industrial Ánimas,

91 190, Xalapa, Veracruz, México.

Phone: +52 228841 - 8900, ext.

13614

Email: juarodriguez@uv.mx

Received: 12 October 2019

Accepted: 27 November 2019

Citation:

Rodríguez:Landa, J. F., Olmos-Vázquez, O. J. Dutra da Costa, B. P. Lima-Maximino, M., Maximino, C., \& Guillén-Ruiz, G. (2020). Actions of progesterone on depression-like behavior in a model of surgical menopause are mediated by GABAA receptors. Salud Mental, 43(1), 43-53.

DOI: $10.17711 /$ SM. $0185-3325.2020 .007$

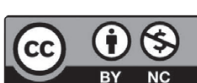

\begin{abstract}
Introduction. In rats, long-term ovariectomy results in low concentrations of steroid hormones and reproduces anxiety- and depression-like behavior after surgical menopause in women. Progesterone produces antidepressant-like effects two weeks post-ovariectomy (i.e., early post-ovariectomy) through actions on $\gamma$-aminobutyric acid-A $\left(G A B A_{A}\right)$ receptors, but its antidepressant-like effects and mechanism of action in rats eight weeks post-ovariectomy (i.e., late post-ovariectomy, considered a model of surgical menopause) remain unknown. Objective. To explore the antidepressant-like effects of progesterone and the participation of GABAA receptors in rats eight weeks post-ovariectomy. Method. Long-term ovariectomized female Wistar rats were treated sub-acutely with vehicle or progesterone $(.5,1$, and $2 \mathrm{mg} / \mathrm{kg})$ and subjected to the open field and forced swim tests, and behavior was compared with cycling or fluoxetine-treated rats. The rats were then pretreated with picrotoxin $(1 \mathrm{mg} / \mathrm{kg}$ ) followed by progesterone $(1 \mathrm{mg} / \mathrm{kg})$ to explore the role of GABAA receptors in long-terminduced depression-like behavior. Results. Long-term ovariectomized rats exhibited depression-like behavior in the forced swim test compared with intact rats, an effect that was not observed in progesterone- and fluoxetine-treated long-term ovariectomized rats. These effects were not attributable to psychomotor alterations. In the open field test, the time spent rearing and grooming was lower in ovariectomized rats compared with intact rats, which was not observed in progesterone- and fluoxetine-treated rats. Picrotoxin blocked the effects of progesterone in both behavioral tests. Discussion and conclusion. These results indicated that sub-acute progesterone treatment reduced depression-like behavior through actions on GABAA receptors in a rat model of surgical menopause.
\end{abstract}

Keywords: Antidepressant, depression-like behavior, GABAA receptor, picrotoxin, progesterone, surgical menopause.

\section{RESUMEN}

Introducción. En la rata, la ovariectomía a largo plazo reproduce algunos síntomas de la menopausia quirúrgica, incluyendo la conducta de tipo depresiva. La progesterona produce efectos tipo antidepresivo en ratas con dos semanas de post-ovariectomía (post-ovariectomía temprana) con participación del receptor $G_{A B A}$, pero se desconoce si este efecto y mecanismo de acción se mantiene en ratas con ocho semanas de post-ovariectomía (post-ovariectomía tardía considerada como un modelo de menopausia quirúrgica). Objetivo. Evaluar el efecto tipo antidepresivo de la progesterona y la participación del receptor GABAA en ratas con ocho semanas de post-ovariectomía. Método. Ratas con ocho semanas de post-ovariectomía fueron tratadas sub-agudamente con vehículo o progesterona $(.5,1$, y $2 \mathrm{mg} / \mathrm{kg}$ ) y comparadas con ratas intactas u ovariectomizadas tratadas con fluoxetina, evaluadas en campo abierto y nado forzado. Posteriormente, se identificó la participación del receptor GABAA en los efectos de progesterona $(1 \mathrm{mg} / \mathrm{kg})$ mediante el pretratamiento con picrotoxina (1 mg/kg). Resultados. En nado forzado, la ovariectomía produjo conductas tipo depresión en comparación con las ratas intactas de la gónada, un efecto prevenido por la administración de progesterona y fluoxetina. En campo abierto, no hubo cambios significativos en la locomoción, pero la conducta vertical y el acicalamiento fueron bajos en las ratas ovariectomizadas respecto a las ratas intactas; lo cual fue prevenido por progesterona y fluoxetina. La picrotoxina bloqueó los efectos de la progesterona en ambas pruebas conductuales. Discusión y conclusión. El tratamiento subagudo con progesterona reduce la conducta tipo depresión inducida en un modelo de menopausia quirúrgica con participación del receptor GABAA.

Palabras clave: Antidepresivo, conducta tipo depresiva, receptor GABAA, picrotoxina, progesterona, menopausia quirúrgica. 


\section{INTRODUCTION}

The premenstrual period, postpartum period, natural menopause, and surgical menopause are characterized by low concentrations of ovarian hormones and associated with symptoms of anxiety and depression that frequently trigger psychiatric disorders (Paoletti et al., 2001; Taylor, 2001). During surgical menopause induced by hysterectomy with or without ovary removal (i.e., oophorectomy), plasma and brain concentrations of the steroid hormones estradiol and progesterone abruptly decrease, and follicle-stimulating hormone levels increase through a reduction of inhibin A (Muttukrishna et al., 2002). In the long-term, these hormonal changes caused by surgical menopause can produce more severe symptoms of anxiety and depression compared with natural menopause (Erekson, Martin, \& Ratner, 2013; Zsakai et al., 2016).

Preclinical studies have shown that long-term ovariectomy (ltOVX) can serve as a rat model of surgical menopause that produces changes similar to oophorectomy in women (Wronski, Dann, Scott, \& Cintrón, 1989; Kimura, Nishihara, Hiruma, \& Funabashi, 1991; Picazo, Estrada-Camarena, \& Hernández-Aragón, 2006). Similar to women who undergo oophorectomy, ovariectomized rats develop endocrine, physiological, and emotional alterations characterized by an early increase in follicle-stimulating hormone levels and decrease in estradiol levels. In the long-term these changes are accompanied by the loss of bone density (i.e., osteoporosis), vasomotor alterations, and changes in the sensitivity of $\gamma$-aminobutyric acid (GABA), GABAergic and dopaminergic receptors in the brain (Kalu, 1991; Bossé \& Di Paolo, 1996). Reductions of glutamate receptor density and cellular proliferation in the hippocampus and other brain structures also occur in ltOVX rats (Lagunas, Calmarza-Font, Diz-Chaves, \& García-Segura, 2010; de Jesús-Burgos, Torres-Llenza, \& Pérez-Acevedo, 2012). Such changes can negatively affect memory processes (McLaughlin, Bimonte-Nelson, Neisewander, \& Conrad, 2008), immune function (Baeza, de Castro, Giménez-Llort, \& de la Fuente, 2010), and cardiovascular function (McGregor et al., 2014). Additionally, an increase in anxiety- and depression-like behavior is detected several weeks post-OVX (Picazo et al., 2006; Puga-Olguín et al., 2019). These findings validate the utility of the rat model of ltOVX for exploring physiological and emotional changes associated with ovarian failure or hysterectomy, based on the criteria of the Stages of Reproductive Aging Workshop (STRAW) in women (Harlow et al., 2012).

Beginning at one-week post-OVX, female rats exhibit anxiety-like behavior compared with females in proestrus-estrus (Puga-Olguín et al., 2019), an ovarian cycle phase that is characterized by high concentrations of steroid hormones. At eight weeks post-OVX, depres- sion-like behavior is observed in the forced swim test (Puga-Olguín et al., 2019). Based on the STRAW criteria, these time-dependent effects of OVX may be related to hormonal changes that occur during the early stage (e.g., an increase in follicle-stimulating hormone levels and decrease in inhibin A and estradiol levels) and late stage (e.g., permanent very low concentrations of inhibin A and estradiol) of menopause (Harlow et al., 2012). In this surgical model of menopause in rats, treatment with $17 \beta$-estradiol (Charoenphandhu, Teerapornpuntakit, Nuntapornsak, Krishnamra, \& Charoenphandhu, 2011; Diz-Chaves et al., 2012) and the phytoestrogen genistein (Rodríguez-Landa, Hernández-Figueroa, Hernández-Calderón, \& Saavedra, 2009b) significantly decreased anxiety-like behavior eight weeks post-OVX through actions on the estrogen receptor $\beta$, a behavioral effect that was similar to diazepam (Rodríguez-Landa, Hernández-López, \& Saavedra, 2012). Interestingly, some neurosteroids (e.g., progesterone and allopregnanolone) that act on $\mathrm{GABA}_{\mathrm{A}}$ receptors were also shown to exert anxiolytic- and antidepressant-like effects when they were intraperitoneally injected or microinjected in the lateral septal nucleus, hippocampus, and nucleus accumbens in adult male rats (Khisti, Chopde, \& Jain, 2000; Molina-Hernández, Tellez-Alcántara, García, López, \& Jaramillo, 2003; Rodríguez-Landa, Contreras, Bernal-Morales, Gutiérrez-García, \& Saavedra, 2007; Rodríguez-Landa, Contreras, \& García-Ríos, 2009a) and female rats two weeks post-OVX (Martínez-Mota, Contreras, \& Saavedra, 1999; Estrada-Camarena, Contreras, Saavedra, Luna-Baltazar, \& López-Ruvalcaba, 2002). Remaining unknown, however, is whether theses effects of progesterone are also evident in rats eight weeks postOVX, a time point at which changes in the GABAergic system have been reported (Herbison \& Fénelon, 1995; Tominaga et al., 2001; Daendee, Thongsong, \& Kalandakanond-Thongsong, 2013).

Ovariectomy has been reported to reduce the density of glutamate receptors and decrease cellular proliferation in the hippocampus and other brain structures (Lagunas et al., 2010; de Jesús-Burgos at al., 2012). Additionally, a reduction of GABA has been observed in the hippocampus (Tominaga et al., 2001). Downregulation of the mRNA expression of $\alpha 2, \alpha 3, \alpha 4, \beta 3$, and $\gamma 1$ subunits of the $\mathrm{GABA}_{\mathrm{A}}$ receptor has also been observed in the amygdala (Herbison \& Fénelon, 1995; Daendee et al., 2013). Steroid hormones are neuromodulators of $\mathrm{GABA}_{\mathrm{A}}$ receptors (Gunn et al., 2015) and were shown to activate GABAergic neurons in the lateral septal nucleus in ovariectomized rats (Briski \& Singh, 2008). Progesterone produces time-dependent anxiolytic-like effects that have been attributed to both non-genomic factors [e.g., direct or indirect modulation of $\mathrm{GABA}_{\mathrm{A}}$ receptors and $\alpha$-amino-3-hydroxy-5-methyl-4-isoxazolepropionic acid and kainate receptors (Barth, Villringer, \& Sacher, 2015) and 
monoamine release (Tonge \& Greengrass, 1971)], and genomic factors (e.g., higher expression of $\mathrm{GABA}_{\mathrm{A}}$ receptor subunits; Nin et al., 2008; Arbo, Andrade, Osterkamp, Gomez, \& Ribeiro, 2014). In the brain, progesterone produces direct or indirect effects. Both progesterone and its metabolite allopregnanolone have been shown to induce behavioral (Schüle, Nothdurfter, \& Rupprecht, 2014) and electrophysiological (e.g., Smith, Waterhouse, Chapin, \& Woodward, 1987; Medina-Maldonado \& Eblen-Zajjur, 2018) effects. Progesterone produces time-dependent effects on different neurotransmitter systems via both direct and indirect mechanisms, and at least part of its mechanism of action converges on the GABAergic system. Thus, low concentrations of steroid hormones post-OVX may decrease GABAergic neurotransmission to produce anxiety- and depression-like behaviors. Interestingly, some symptoms of mental disorders associated with a reduction of steroid hormones may be treated by drugs that interact with specific neurotransmitter systems and activate neurosteroidogenesis. Fluoxetine and different selective serotonin reuptake inhibitors (SSRIs) have been shown to increase the activity of $3 \alpha$-hydroxysteroid dehydrogenase in humans and laboratory animals (Griffin \& Mellon, 1999; Pinna, Costa, \& Guidotti, 2006) and facilitate the biotransformation of $5 \alpha$-dihydroprogesterone (i.e., a metabolite of progesterone) to allopregnanolone, the concentration of which was shown to increase in the hippocampus, olfactory bulb, and frontal cortex in castrated rats (Uzunov, Cooper, Costa, \& Guidotti, 1996; Guidotti \& Costa, 1998). These findings may explain the ability of SSRIs to rapidly alleviate symptoms of anxiety and depression that are associated with low concentrations of steroid hormones (Pinna, 2010), thus opening the possibility of exploring non-classic mechanisms by which progesterone and its $\alpha$-reduced metabolites exert antidepressant-like effects. Such studies will broaden our knowledge of neurosteroids as potential anxiolytic and antidepressant agents and contribute to the development of therapeutic strategies for this group of patients who are characterized by low concentrations of ovarian hormones, such as in oophorectomized women.

GABAergic compounds, including neurosteroids (e.g., progesterone), and their $\alpha$-reduced metabolites (e.g., allopregnanolone), exert anxiolytic- and antidepressant-like effects through actions on $\mathrm{GABA}_{\mathrm{A}}$ receptors. $\mathrm{GABA}_{\mathrm{A}}$ receptors are modified by ltOVX, but the effects of progesterone have not been evaluated in ltOVX rats. The present study investigated the effects of several sub-acute doses of progesterone on depression-like behavior in female rats that were subjected to OVX-induced surgical menopause at eight weeks post-OVX. We explored the participation of $\mathrm{GABA}_{\mathrm{A}}$ receptors in the sub-acute actions of progesterone in these effects.

\section{METHOD}

\section{Animals}

Eighty-two adult female Wistar rats (three months old), weighing 200-250 $\mathrm{g}$ at the beginning of the study, were used. The rats were housed in Plexiglas cages (4-5 rats/cage) under a $12 \mathrm{~h} / 12 \mathrm{~h} \mathrm{light/dark} \mathrm{cycle} \mathrm{(lights} \mathrm{on} \mathrm{at} \mathrm{7:00} \mathrm{AM)}$ with an average temperature of $25^{\circ} \mathrm{C} \pm 1{ }^{\circ} \mathrm{C}$ and ad libitum access to water and food (Nutri-cubos, Purina, Agribrands Purina Mexico, Mexico City, Mexico). All of the rats, with the exception of intact rats, were ovariectomized at three months of age. The behavioral tests were performed eight weeks post-OVX.

\section{Vaginal smears}

Before starting the experiments, we obtained daily vaginal smears from all of the rats. Only females with three continuous regular cycles (4-5 days) were included in the study. On the day of behavioral testing, vaginal smears were obtained only from rats that served as ovarian cycle controls immediately after the open field test to identify their estrous cycle phase. Vaginal smears were collected by gently inserting the rounded tip of a Pasteur pipette into the entrance of the vaginal canal, flushing saline in and out, and placing the fluid onto a microscope slide. The ovarian cycle phase was immediately determined by optical microscopy (40× magnification) according to Rhodes, Balestreire, Czambel, and Rubin (2002). The rats were classified into two groups for statistical analysis: proestrus-estrus (P-E) and metestrus-diestrus (M-D). Previous studies showed that P-E is characterized by low anxiety-like behavior, and M-D is characterized by high anxiety-like behavior (Walf, Sumida, \& Frye, 2006; Puga-Olguín et al., 2019) and insensitivity to diazepam treatment (Gouveia, Antunes, Maximino, \& Morato, 2009).

\section{Ovariectomy}

At three months of age, the rats were ovariectomized. Surgery was performed through an abdominal ventral incision under deep anesthesia with sodium pentobarbital (60 $\mathrm{mg} / \mathrm{kg}$, i.p., Cheminova de México, Mexico City, Mexico; Reg. SAGARPA Q-7048-044) with atropine sulfate pretreatment $(.05 \mathrm{mg} / \mathrm{kg}$, i.p., Sigma-Aldrich, St. Louis, MO, USA). The oviducts and ovaries were ligated (approximately $1 \mathrm{~cm}$ from the ovary) and then removed. The tissue was carefully cleaned with benzalkonium chloride (Medipharm, San Luis Río Colorado, Sonora, Mexico). The muscle and skin were then separately sutured. Analgesic-antipyretic medication $(50 \mathrm{mg} / \mathrm{kg}$ dipyrone, i.m., Virbac Animal Health, Guadalajara, Mexico) was administered for four consecutive days to minimize postsurgical 
pain. After surgery, the rats were returned to the housing facilities for eight weeks until vehicle, progesterone, and fluoxetine treatment began. Fluoxetine was used as a positive control reference antidepressant drug that has been shown to exert antidepressant-like activity in ovariectomized rats (Estrada-Camarena, López-Rubalcava, Hernández-Aragón, Mejía-Mauries, \& Picazo, 2011).

\section{Experiment 1: Progesterone dose-response curve}

Fifty-eight rats were randomly assigned to seven experimental groups. Three control groups were used: non-OVX group in P-E (P-E group, $n=8$; this phase is considered to be associated with high concentrations of ovarian hormones), non-OVX group in M-D (M-D group, $n=8$; this phase is considered to be associated with low concentrations of ovarian hormones), and OVX group treated with 5 $\mathrm{mg} / \mathrm{kg}$ fluoxetine at eight weeks post-OVX (FX group, $n=$ $8)$. Likewise, four experimental groups were used $(n=8-9$ / group): OVX group treated with $.05 \mathrm{mg} / \mathrm{kg}$ progesterone (water-soluble, Sigma-Aldrich, St. Louis MO, USA) eight weeks post-OVX (P .5 group), OVX group treated with 1 $\mathrm{mg} / \mathrm{kg}$ progesterone eight weeks post-OVX (P1 group), OVX group treated with $2 \mathrm{mg} / \mathrm{kg}$ progesterone eight weeks post-OVX (P2 group), and OVX group treated with vehicle (.9\% saline) eight weeks post-OVX (VE group). All of the treatments were administered intraperitoneally 24 and $2 \mathrm{~h}$ before behavioral testing (Martínez-Mota et al., 1999; Estrada-Camarena et al., 2011). The behavioral tests were performed between 10:00 AM and 1:00 PM.

\section{Experiment 2: $\mathrm{GABA}_{A}$ receptor antagonism}

Twenty-four ltOVX rats were randomly assigned to three independent groups ( $n=8$ /group): vehicle $(.9 \%$ saline; $\mathrm{VE}$ group), $1 \mathrm{mg} / \mathrm{kg}$ progesterone (P1 group), and $1 \mathrm{mg} / \mathrm{kg}$ progesterone plus $1 \mathrm{mg} / \mathrm{kg}$ picrotoxin ( $\mathrm{P} 1+\mathrm{Pic}$ group). Vehicle, progesterone, and fluoxetine were administered 24 and 2 $\mathrm{h}$ before behavioral testing. Picrotoxin or its vehicle was administered $30 \mathrm{~min}$ before the second injection of progesterone. The administration schedule was based on previous studies, in which $1 \mathrm{mg} / \mathrm{kg}$ picrotoxin did not produce significant effects on behavioral variables in the open field test or forced swim test but prevented the antidepressant-like effects of GABAergic compounds (Rodríguez-Landa et al., 2007; Rodríguez-Landa et al., 2018). All of the treatments were administered intraperitoneally in a volume of $1 \mathrm{ml} /$ $\mathrm{kg}$. The effects of the treatments were evaluated in the open field test and then in the forced swim test.

\section{Behavioral tests}

We compared the behavioral effects of progesterone in OVX rats, rats in different ovarian cycle phases, and rats treated with fluoxetine. The rats were sequentially tested in the open field test $(5 \mathrm{~min})$ and then in the forced swim test. Approximately, 2 min elapsed between tests. One day before starting the treatments, the rats underwent a pretest session in the open field test and then in the forced swim test $(15 \mathrm{~min})$, the results of which were discarded from the statistical analysis because these sessions were considered only habituation to the experimental conditions (Porsolt, Le Pichon, \& Jalfre, 1977).

\section{Open field test}

To identify possible nonspecific psychomotor effects (e.g., hypoactivity or hyperactivity) of the surgical manipulation, ovarian cycle phases, or treatments, the rats were evaluated in the open field test $2 \mathrm{~h}$ after the second injection of the treatments. Nonspecific motor changes could interfere with behavioral activity in the forced swim test, thus masking behavioral responses that are associated with emotional states. The open field consisted of an opaque Plexiglas cage (44 cm length $\times 33 \mathrm{~cm}$ width $\times 20 \mathrm{~cm}$ height). The floor was delineated into 12 squares $\left(11 \mathrm{~cm}^{2}\right)$. The rats individually underwent a 5-min locomotor activity test. A digital video camera (Sony, DCR-SR42, 40× optical zoom, Carl Zeiss lens) was installed above the cage to record activity. Two independent observers who were blind to the treatments measured behavioral variables until at least $95 \%$ agreement was reached between observers.

At the onset of the test, the rat was gently placed in one of the corners of the cage, and the following variables were measured: number of squares crossed (a square crossing was recorded when the rat passed from one square to another with its hind legs), time spent rearing (rearing was recorded when the rat acquired a vertical posture relative to the cage floor; this behavior is considered an indicator of exploration that is lower in animals that exhibit "stress" or "despair"), and time spent grooming (i.e., paw licking, nose/face grooming, head washing, body grooming/ scratching, leg licking, and tail/genital grooming). Grooming is considered an indicator of stress in rodents (Kalueff \& Tuohimaa, 2005). This behavior is lower in rats that exhibit "stress" or "despair" and recovered by antidepressant drug and neurosteroid treatment (e.g., progesterone and allopregnanolone; Contreras, Rodríguez-Landa, Bernal-Morales, Gutiérrez-García, \& Saavedra, 2011).

After each test session, the Plexiglas cage was carefully cleaned with a $15 \%$ ethanol solution to avoid immediate behaviors that are caused by sensory stimuli (i.e., volatile substances) present in the urine of previous rats.

\section{Forced swim test}

After the open field test, the rats were individually forced to swim in a rectangular pool $(50 \mathrm{~cm} \times 30 \mathrm{~cm} \times 60 \mathrm{~cm})$ 
filled with $25^{\circ} \mathrm{C} \pm 1^{\circ} \mathrm{C}$ water to a depth of $25 \mathrm{~cm}$, which has been validated for the detection of antidepressant-like effects of clinically effective antidepressant drugs (Contreras, Martínez-Mota, \& Saavedra, 1998; Contreras, Rodríguez-Landa, Gutiérrez-García, \& Bernal-Morales, 2001), neurosteroids (Martínez-Mota et al., 1999; Rodríguez-Landa et al., 2007), and plant extracts (Molina, Contreras, \& Tellez-Alcantara, 1999; Lozano-Hernández et al., 2010). Approximately $2 \mathrm{~h}$ after drug administration, the rats were evaluated in a 5-min forced swim test session. The following variables were evaluated: latency to the first episode of immobility (i.e., elapsed time since the rat was introduced to the pool until the first episode of immobility) and total immobility time. Immobility was recorded when the rat floated for more than $1 \mathrm{~s}$ without making vigorous movements that led to displacement in the pool and only maintained its head above the water surface. All of the experimental sessions were video recorded. Two independent observers who were blind to the treatment measured the behavioral variables until at least 95\% agreement was reached between observers.

\section{Statistical analysis}

The behavioral data were analyzed using the Kruskal-Wallis test followed by Dunn's post hoc test. Values of $p \leq .05$ were considered statistically significant. The results are presented as individual data points overlaid on boxplots.

\section{Ethical considerations}

All of the experimental procedures were performed according to official Mexican guidelines (Especificaciones Técnicas para la Producción, Cuidado y Uso de Animales de Laboratorio; Norma Oficial Mexicana, 1999) and international ethical guidelines, based on the National Research Council Guide for the Care and Use of Laboratory Animals (National Research Council, 2011). All efforts were made to minimize suffering of the animals.

\section{RESULTS}

\section{Progesterone dose-response curve}

Open field test

No significant differences were found between groups in the number of crossings in the open field test $\left(\mathrm{H}_{6}=9.723\right.$, $p=.137$; Figure 1A). Significant differences in grooming were found between groups $\left(\mathrm{H}_{6}=41.526, p<.001\right)$. The post hoc test revealed no significant differences in grooming between the M-D and P-E groups, but vehicle-treated ltOVX animals exhibited a decrease in grooming compared with the P-E and M-D groups. These effects that were as- sociated with ltOVX were not observed when 1 or $2 \mathrm{mg} / \mathrm{kg}$ progesterone or fluoxetine was administered. Progesterone at a dose of $.5 \mathrm{mg} / \mathrm{kg}$ did not affect grooming (Figure 1B).

The analysis revealed significant differences in the time spent rearing between groups $\left(\mathrm{H}_{6}=38.451, p<.001\right)$. The vehicle-treated ltOVX group exhibited a decrease in the time spent rearing compared with the P-E and M-D groups, whereas this effect was not observed in rats that were treated with 1 or $2 \mathrm{mg} / \mathrm{kg}$ progesterone or fluoxetine. Progesterone at a dose of $.5 \mathrm{mg} / \mathrm{kg}$ did not affect the time spent rearing (Figure $1 \mathrm{C})$.

\section{Forced swim test}

The latency to the first episode of immobility in the forced swim test was significantly different between groups $\left(\mathrm{H}_{6}=\right.$ $48.538, p<.001)$. The latency to the first episode of immobility was lower in the vehicle-treated group compared with the P-E and M-D groups (Figure 2A), but this effect of OVX was not detected in rats that were treated with 1 or $2 \mathrm{mg} / \mathrm{kg}$ progesterone or fluoxetine; even the values of this variable were higher than P-E and M-D groups. Progesterone- and fluoxetine-treated rats had a significantly higher latency to the first episode of immobility compared with the P-E and
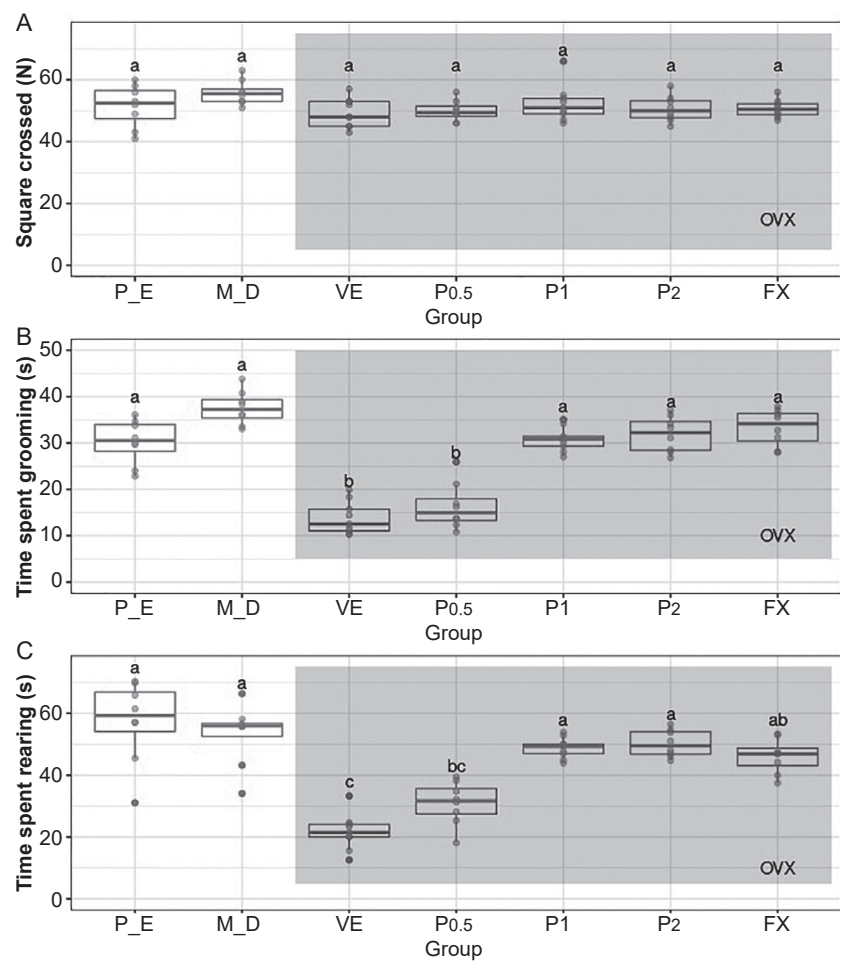

Figure 1. Behaviors evaluated in the locomotor activity test. Number of crossed squares (A), time spent in grooming (B) and time spent in rearing $(C)$. Data are presented as individual data points (dots) superimposed over the median \pm interquartile ranges. Different letters indicate differences at the $p<.05$ level. P-E, proestrus-estrus phase; $M-D$, metestrus-diestrus group; VE, Vehicle; P, progesterone, FX, fluoxetine; OVX ovariectomized rats (shading area). 

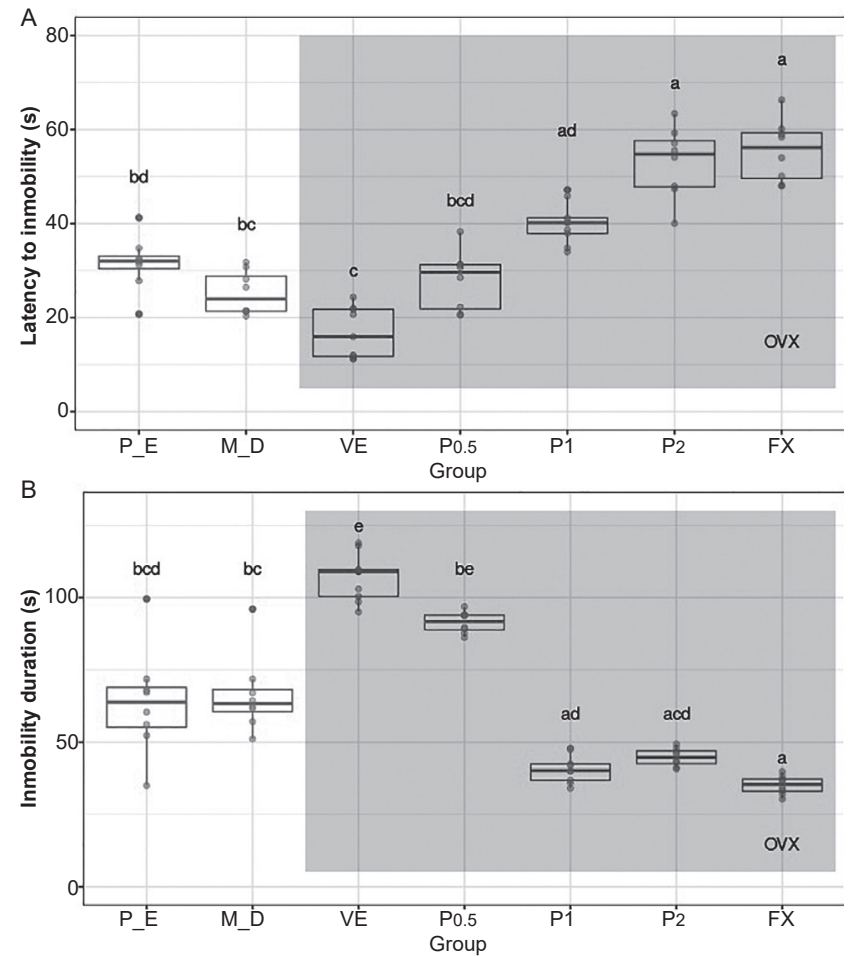

Figure 2. Variables evaluated in the forced swim test. Latency to first immobility (A), total time of immobility (B). Data are presented as individual data points (dots) superimposed over the median \pm interquartile ranges. Different letters indicate differences at the $p<.05$ level. P-E, proestrus-estrus phase; M-D, metestrus-diestrus group; VE, vehicle; P, progesterone, FX, fluoxetine; OVX ovariectomized rats (shading area).

M-D groups. No significant effect of $.5 \mathrm{mg} / \mathrm{kg}$ progesterone was detected on this variable.

The total immobility time was also significantly different between groups $\left(\mathrm{H}_{6}=49.220, p<.001\right)$. The vehicle-treated ltOVX group exhibited a higher total immobility time compared with the P-E and M-D groups, but this effect was not observed in rats treated with 1 or $2 \mathrm{mg} / \mathrm{kg}$ progesterone or fluoxetine; even the total immobility time in those groups was higher than P-E and M-D groups. Progesterone at a dose of $.5 \mathrm{mg} / \mathrm{kg}$ did not significantly affect this variable (Figure 2B).

\section{$\mathrm{GABA}_{\mathrm{A}}$ receptor antagonism}

\section{Open field test}

The number of crossings was not significantly different between groups $\left(\mathrm{H}_{2}=2.906, p<.234\right.$; Figure 3A). Significant differences in the time spent grooming were found between groups $\left(\mathrm{H}_{2}=16.485, p<.001\right)$. The progesterone-treated group spent more time grooming compared with the vehicle-treated group, and this effect was prevented by pretreatment with picrotoxin (Figure 3B). The progesterone-treated group exhibited an increase in rearing compared with the
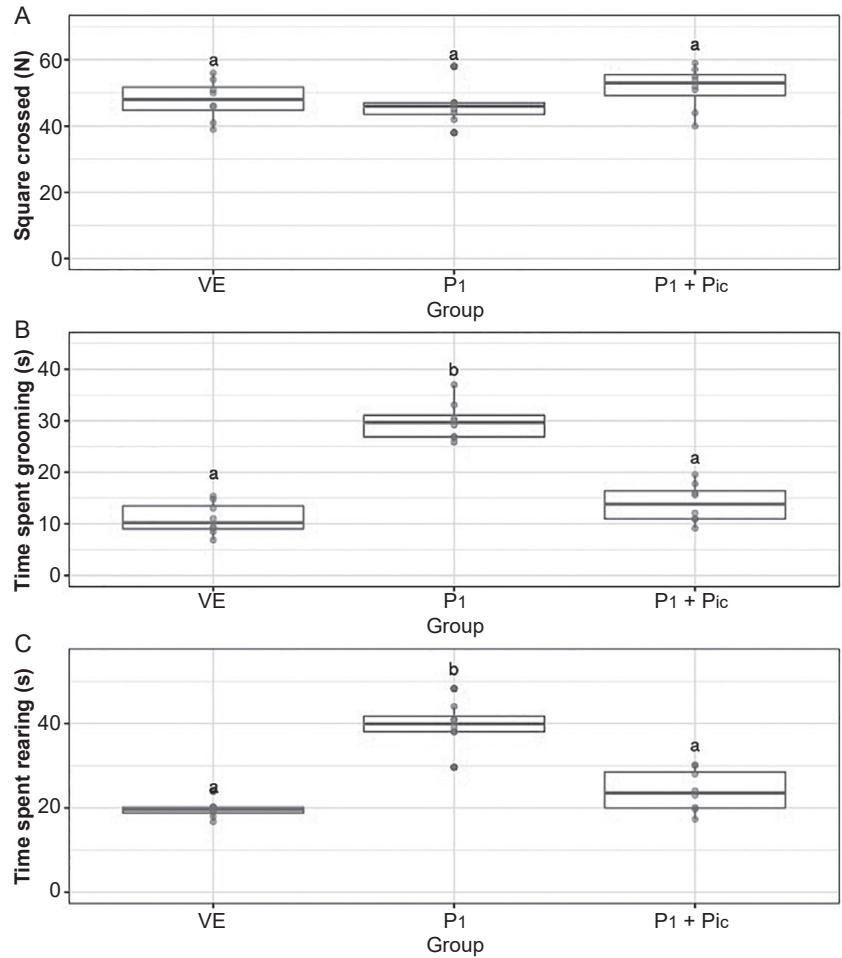

Figure 3. Behaviors evaluated in the locomotor activity test. Number of squares crossed $(A)$, time spent in grooming $(B)$ and time spent in rearing $(\mathrm{C})$. Data are presented as individual data points (dots) superimposed over the median \pm interquartile ranges. Different letters indicate differences at the $p<.05$ level. VE, Vehicle; P, progesterone; Pic, picrotoxin.

vehicle-treated group $\left(\mathrm{H}_{2}=16.035, p<.001\right)$, and this effect was prevented by picrotoxin (Figure 3C).

\section{Forced swim test}

The latency to the first episode of immobility was significantly different between groups $\left(\mathrm{H}_{2}=17.565, p<.001\right)$. The progesterone-treated group exhibited a longer latency to the first episode of immobility compared with the vehicle-treated group, and this effect was prevented by pretreatment with picrotoxin (Figure 4A). The progesterone-treated group exhibited a lower total immobility time compared with the vehicle-treated group $\left(\mathrm{H}_{2}=15.860, p<.001\right)$, and this effect on immobility was blocked by picrotoxin (Figure 4B).

\section{DISCUSSION AND CONCLUSION}

The present study explored the effect of progesterone on depression-like behavior that is associated with ltOVX in female Wistar rats, and this effect was compared with rats treated with fluoxetine and rats in the P-E and M-D phases of the ovarian cycle. We also investigated the participation of $\mathrm{GABA}_{\mathrm{A}}$ receptors in the mechanism of action of proges- 

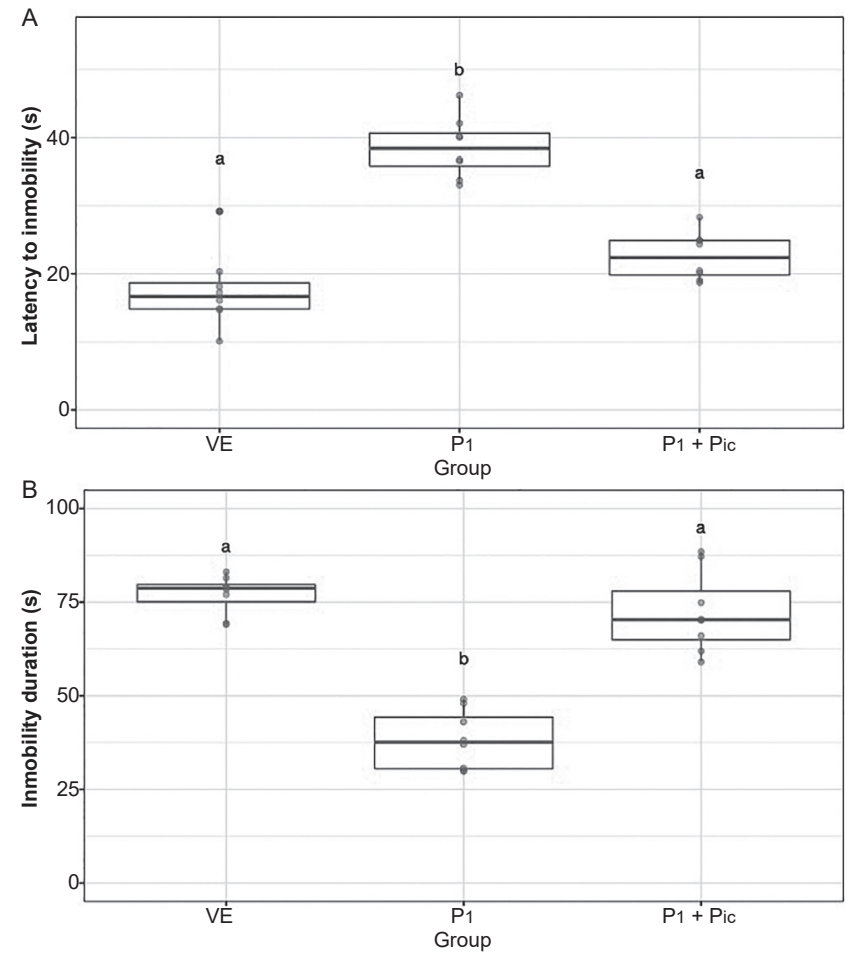

Figure 4. Variables evaluated in the forced swim test. Latency to first immobility (A), total time of immobility (B). Data are presented as individual data points (dots) superimposed over the median \pm interquartile ranges. Different letters indicate differences at the $p<.05$ level. VE, Vehicle; P, progesterone; Pic, picrotoxin.

terone by blocking chloride ion channels with picrotoxin. In ltOVX rats, progesterone exerted behavioral effects that were similar to fluoxetine, reaching values that were similar to rats in P-E when high concentrations of ovarian hormones are observed (Lagunas et al., 2010). Furthermore, picrotoxin prevented the antidepressant-like effects of progesterone, suggesting the involvement of $\mathrm{GABA}_{\mathrm{A}}$ receptors in the pharmacological actions of progesterone or its $\alpha$-reduced metabolites in ltOVX rats, although other neurotransmitter systems (e.g., serotonin and dopamine) may also be involved in these actions. The present findings support the potential therapeutic efficacy of progesterone in ameliorating symptoms of depression in women with low concentrations of steroid hormones, such as after oophorectomy.

The forced swim test is a valid behavioral model used to detect potential antidepressant-like effects of various substances. In this test, more immobility is observed in the second trial of the test in animals that exhibit depression-like behavior. Clinically effective antidepressant drugs reduce the total immobility time, which is interpreted as an antidepressant-like effect (Porsolt et al., 1977; Nestler, Gould, \& Manji, 2002). In the present study, the rats at eight weeks post-OVX had a higher total immobility time compared with rats in P-E and M-D, which is consistent with the depression-like state previously reported in ltOVX rats (Puga-Olguín et al., 2019). Interestingly, a sub-acute injection of progesterone prevented the establishment of immobility in ltOVX rats, thus indicating an antidepressant-like effect similar to clinically effective antidepressant drugs (Porsolt et al., 1977; Kara, Stukalin, \& Einat, 2018). Progesterone and its $\alpha$-reduced metabolites have been implicated in the underlying mechanism of depression symptoms. Some disorders related to female reproductive life, such as premenstrual syndrome and post-partum depression, are characterized by low concentrations of progesterone and allopregnanolone, among others. Interestingly, SSRIs, in addition to activating the serotonergic system, have been shown to increase the cerebrospinal fluid content of neurosteroids (e.g., the progesterone metabolite allopregnanolone) by activating $3 \alpha$-hydroxysteroid-dehydrogenase in humans and rodents (Uzunov et al., 1996; Griffin \& Mellon, 1999; Uzunova et al., 1998). In ovariectomized rats, progesterone treatment decreased depression-like behavior without influencing intracellular progestin receptors (Frye, 2011a; Frye, 2011b), suggesting that the acute antidepressant-like effects of progesterone may occur independently of progestin receptors (Frye, 2011b). This action could involve the modulation of ionotropic receptors. Therefore, the possible activation of $\mathrm{GABA}_{\mathrm{A}}$ receptors could occur by allosteric modulation exerted by progesterone itself of its biotransformation to allopregnanolone (Carver \& Reddy, 2013; Reddy, 2018). Nonetheless, other neurotransmitter systems, such as the serotonergic and dopaminergic systems, may also be involved in these actions, similar to other antidepressant drugs that interact with the GABAergic system (Ago et al., 2016; Hasebe et al., 2017).

The latency to the first episode of immobility is considered an indicator of the magnitude of the first effort that rats expend to cope with the stressful situation of being forced to swim (Contreras et al., 1998; Espejo \& Miñano, 1999). A short latency to the first episode of immobility is considered a complementary indicator of depression-like behavior. A longer latency indicates an antidepressant-like effect that occurs with the administration of clinically effective antidepressant drugs (Contreras et al., 1998; Contreras et al., 2001; Castagné, Porsolt, \& Moser, 2009). In the present study, the latency to the first episode of immobility was shorter in ltOVX rats than in the P-E and M-D groups. The latency increased in progesterone- and fluoxetine-treated rats, thus supporting an antidepressant-like effect under our experimental conditions.

Interestingly, the effects of progesterone and fluoxetine on the latency to the first episode of immobility and total immobility time in the forced swim test in ltOVX rats were greater than in normally cycling rats with natural concentrations of steroid hormones. Allopregnanolone is a metabolite of progesterone. Allopregnanolone can also be produced by the actions of fluoxetine beyond 
its actions on the serotonergic system. This suggests that progesterone or allopregnanolone may further activate neurotransmitter receptors in ovariectomized rats to produce antidepressant-like effects. In the present study, we injected progesterone and fluoxetine twice (24 and $2 \mathrm{~h}$ before behavioral testing). The first drug injection, which can acutely produce antidepressant-like effects (Contreras et al., 2011), may sensitize or change the conformation of receptor subunits. Therefore, the second drug injection may produce a greater effect than the first, as it probably occurred. However, specific protocols are required to test this possibility.

In the present study, no significant changes in spontaneous locomotor activity were observed, indicating that the effects of progesterone and fluoxetine in the forced swim test were not attributable to spontaneous motor effects and thus likely associated with a positive motivational state that resulted from the antidepressant-like effect of the neurosteroid. Additionally, rearing and grooming are behavioral indicators of emotional states in rats when they are exposed to novel environments (Gilad, Rabey, Eliyayev, \& Gilad, 2000). The rats at eight weeks post-OVX had the lowest level of rearing and grooming in the open field test, which could be associated with a depression-like state that was previously reported in ovariectomized rats (Rodríguez-Landa, Rodríguez-Santiago, Rovirosa-Hernández, García-Orduña, \& Carro-Juárez, 2014; Rodríguez-Landa et al., 2017). This suggests low motivation to auto-groom and explore, which is commonly observed in rats that exhibit "anxiety" or "despair" (Rodríguez-Landa et al., 2009b; Contreras et al., 2011; Puga-Olguín et al., 2019). These changes in grooming and rearing behavior associated with ltOVX were prevented by progesterone and fluoxetine, reaching values that were similar to rats in P-E. Therefore, alterations of grooming and rearing that were associated with progesterone and fluoxetine treatment could be a behavioral component of the antidepressant-like effect that was detected in the forced swim test.

The present study also explored the participation of chloride ion channels of the $\mathrm{GABA}_{\mathrm{A}}$ receptor in the antidepressant-like effects of progesterone. $\mathrm{GABA}_{\mathrm{A}}$ receptors appear to be involved in the antidepressant-like actions of progesterone, possibly through the allosteric modulation of these receptors and modification of structural combinations of its subunits. These conformational changes impact ion conductance through the channel and ultimately produce pharmacological actions (Smith et al., 1987). Therefore, pretreatment with picrotoxin may prevent the anxiolytic- and antidepressant-like effects of some neurosteroids, including progesterone and allopregnanolone. Picrotoxin is a noncompetitive $\mathrm{GABA}_{\mathrm{A}}$ receptor antagonist that blocks the opening of chloride ion channels and prevents the antidepressant-like effects of GABAergic compounds, including neurosteroids, in male and female rats (Estrada-Camarena et al., 2002; Rodríguez-Landa et al., 2009b). Picrotoxin also blocked the antidepressant-like effect of progesterone in ltOVX rats in the present study. Other effects of picrotoxin, however, cannot be fully discarded. Picrotoxin is traditionally viewed as a noncompetitive $\mathrm{GABA}_{\mathrm{A}}$ and $\mathrm{GABA \sigma}$ receptor antagonist, but parallel effects on other anion-selective ligand-gated ion channels, such as glycine receptors (Pribilla, Takagi, Langosch, Bormann, \& Betz, 1992) and glutamate-gated chloride channels (Etter et al., 1999), have also been reported. Moreover, picrotoxin has been shown to noncompetitively inhibit cation-selective serotonin 5-hydroxytryptamine-3A receptors (Das, Bell-Horner, Machu, \& Dillon, 2003). Importantly, the doses of picrotoxin used in the present study are devoid of intrinsic effects on behavior in rodent tests of anxiety and depression (Rodríguez-Landa, García-Ríos, Cueto-Escobedo, Bernal-Morales, \& Contreras, 2013). Therefore, picrotoxin likely did not exert sufficient actions on neuronal activity to influence depression-like behavior under our experimental conditions. Nonetheless, the present results should be interpreted with caution.

In the present study, the GABAergic system was likely fully functional in ltOVX rats that exhibited an antidepressant-like effect of progesterone. However, we cannot discard the possible participation of allopregnanolone, the $\alpha$-reduced metabolite of progesterone, in the effects that were detected herein. The antidepressant-like effects of progesterone in the forced swim test could indeed be produced by its biotransformation to allopregnanolone (Contreras et al., 2011). Finasteride, an inhibitor of $3 \alpha$-hydroxysteroid dehydrogenase, prevented antidepressant-like effects during natural physiological states that are characterized by high concentrations of progesterone, such as during pregnancy, lactation, and proestrus (Frye \& Walf, 2002; 2004). The antidepressant-like effects of both progesterone and allopregnanolone were reported to be prevented by $\mathrm{GABA}_{\mathrm{A}}$ receptor antagonism (Rodríguez-Landa et al., 2007; 2009a), thus supporting the participation of $\mathrm{GABA}_{\mathrm{A}}$ receptors in the mechanism of action of progesterone.

Ovariectomy reduces the density of glutamate receptors in some brain structures (Lagunas et al., 2010; de Jesús-Burgos et al., 2012), which reduces GABAergic neurotransmission and possibly contributes to the expression of depressive symptoms. The activation of glutamatergic receptors by agonists was shown to reactivate the GABAergic system in ovariectomized rats, and this activation depended on the concentration of steroid hormones that modulate membrane metabotropic glutamate receptors and participate in the expression of behavioral responses associated with anxiety and depression (de Jesús-Burgos et al., 2012). Similarly, ltOVX was shown to reduce the concentration of GABA in the hippocampus (Tominaga et al., 2001) and downregulate the mRNA expression of some subunits of the $\mathrm{GABA}_{\mathrm{A}}$ receptor in the amygdala (Herbison \& Fénelon, 1995; Daendee et al., 2013). These changes in the brain may contribute to the anxiety- and depression-like behavior associated with 
ltOVX (Puga-Olguín et al., 2019). In the present study, the sub-acute injections of progesterone produced antidepressant-like effects, probably associated with the reactivation of $\mathrm{GABA}_{\mathrm{A}}$ receptors, which is consistent with previous studies (Gunn et al., 2015) and was shown to occur particularly in brain regions related to the neurobiology of depression (Briski \& Singh, 2008).

The present study has limitations. First, we did not control for whether the antidepressant-like effects that were observed herein were produced by progesterone or its biotransformation to allopregnanolone. Second, because we only tested the effect of one nonselective $\mathrm{GABA}_{\mathrm{A}}$ receptor antagonist, we cannot confirm or refute the possible participation of other neurotransmitter systems in the behavioral effects that were observed. Nonetheless, our findings strongly suggest that the antidepressant-like effects of progesterone or allopregnanolone identified in a surgical menopause model involve $\mathrm{GABA}_{\mathrm{A}}$ receptors. The present findings contribute to our understanding of the antidepressant-like actions progesterone in a rat model of surgical menopause, which contribute to knowledge of antidepressant effects of progesterone and progestins in menopause transition (Maki et al., 2019). Further studies should explore the efficacy of progesterone and allopregnanolone in modulating different neurotransmitter systems to ameliorate clinical symptoms of depression, particularly in women with low concentrations of ovarian hormones, such as during natural or surgical menopause.

\section{Funding}

This study is part of SIREI project no. DGI: 266502018125 registered to Juan Francisco Rodríguez-Landa, which was partially supported by Sistema Nacional de Investigadores CONACyT-México (Exp. 32753) and Programa "Habilitación del Perfil Internacional para Académicos de la Universidad Veracruzana - HAPI-UV, Convocatoria 2019-2" during a research visit to the Laboratório de Neurociências e Comportamento, Faculdade de Psicologia, Instituto de Estudos em Saúde e Biológicas, Universidade Federal do Sul e Sudeste do Pará, Marabá, Pará, Brazil.

\section{Conflict of interest}

The authors declare no conflicts of interest.

\section{Acknowledgements}

The authors thank Consejo Nacional de Ciencia y Tecnología (CONACyT-México) for awarding a fellowship to Oscar Jerónimo Olmos-Vázquez for doctorate studies in neuroethology (Reg. 574269). The authors thank Michael Arends for editing the English of the manuscript.

\section{REFERENCES}

Ago, Y., Hasebe, S., Hiramatsu, N., Mori, K., Watabe, Y., Onaka, Y., ... Matsuda, T. (2016). Involvement of GABAA receptor in 5-HT1A and $\sigma_{1}$ receptor synergism on prefrontal dopaminergic transmission under circulating neurosteroid deficiency. Psychopharmacology, 233(17), 3125-3134. doi: 10.1007/s00213-016-4353-3
Arbo, B. D., Andrade, S., Osterkamp, G., Gomez, R., \& Ribeiro, M. F. (2014). Asymmetric effects of low doses of progesterone on GABA(A) receptor $\alpha 4$ subunit protein expression in the olfactory bulb of female rats. Canadian Journal of Physiology and Pharmacology, 92(12), 1045-1049. doi: 10.1139/ cjpp-2014-0307

Baeza, I., de Castro, N. M., Giménez-Llort, L., \& de la Fuente, M. (2010). Ovariectomy, a model of menopause in rodents, causes a premature aging of the nervous and immune systems. Journal of Neuroimmunology, 219(1-2), 90-99. doi: 10.1016/j.jneuroim.2009.12.008

Barth, C., Villringer, A., \& Sacher, J. (2015). Sex hormones affect neurotransmitters and shape the adult female brain during hormonal transition periods. Frontiers in Neuroscience, 9, 37. doi: 10.3389/fnins.2015.00037

Bossé, R., \& Di Paolo, T. (1996). The modulation of brain dopamine and GABAA receptors by estradiol: a clue for CNS changes occurring at menopause. Cellular and Molecular Neurobiology, 16(2), 199-212. doi: 10.1007/BF02088176

Briski, K. P., \& Singh, S. R. (2008). Hindbrain neuroglucopenia elicits site-specific transcriptional activation of glutamate decarboxylase-immunopositive neurons in the septopreoptic area of female rat brain. Neuroendocrinology, 87(2), 113120. doi: $10.1159 / 000109663$

Carver, C. M., \& Reddy, D. S. (2013). Neurosteroid interactions with synaptic and extrasynaptic GABAA receptors: regulation of subunit plasticity, phasic and tonic inhibition, and neuronal network excitability. Psychopharmacology, 230(2), 151-188. doi: 10.1007/s00213-013-3276-5

Castagné, V., Porsolt, R. D., \& Moser. P. (2009). Use of latency to immobility improves detection of antidepressant-like activity in the behavioral despair test in the mouse. European Journal of Pharmacology, 616(1-3), 128-133. doi: 10.1016/j.ejphar.2009.06.018

Charoenphandhu, J., Teerapornpuntakit, J., Nuntapornsak, A., Krishnamra, N., \& Charoenphandhu, N. (2011). Anxiety-like behaviors and expression of SERT and TPH in the dorsal raphé of estrogen- and fluoxetine-treated ovariectomized rats. Pharmacology Biochemistry and Behavior, 98(4), 503-510. doi: 10.1016/j. pbb.2011.02.023

Contreras, C. M., Martínez-Mota, L., \& Saavedra, M. (1998). Desipramine restricts estral cycle oscillations in swimming. Progress in Neuro-psychopharmacology and Biological Psychiatry, 22(7), 1121-1128. doi: 10.1016/s02785846(98)00066-9

Contreras, C. M., Rodríguez-Landa, J. F., Bernal-Morales, B., Gutiérrez-García A. G., \& Saavedra, M. (2011). Timing of progesterone and allopregnanolone effects in a serial forced swim test. Salud Mental, 34(4), 309-314.

Contreras, C. M., Rodríguez-Landa, J. F., Gutiérrez-García, A. G., \& BernalMorales, B. (2001). The lowest effective dose of fluoxetine in the forced swim test significantly affects the firing rate of lateral septal nucleus neurones in the rat. Journal of Psychopharmacology, 15(4), 231-236. doi: $10.1177 / 026988110101500401$

Daendee, S., Thongsong, B., \& Kalandakanond-Thongsong, S. (2013). Effects of time of estrogen deprivation on anxiety-like behavior and GABAA receptor plasticity in ovariectomized rats. Behavioural Brain Research, 246, 86-93. doi: 10.1016/j.bbr.2013.03.008

Das, P., Bell-Horner, C. L., Machu, T. K., \& Dillon, G. H (2003). The GABAA receptor antagonist picrotoxin inhibiths 5-hydroxytryptamine type $3 \mathrm{~A}$ receptors. Neuropharmacology, 44(4), 431-438. doi: 10.1016/S0028-3908(03)00032-7

Diz-Chaves, Y., Kwiatkowska-Naqvi, A., Von Hülst, H., Pernía, O., Carrero, P., \& Garcia-Segura, L. M. (2012). Behavioral effects of estradiol therapy in ovariectomized rats depend on the age when the treatment is initiated. Experimental Gerontology, 47(1), 93-99. doi: 10.1016/j.exger.2011.10.008

Erekson, E. A., Martin, D. K., \& Ratner, E. S. (2013). Oophorectomy: the debate between ovarian conservation and elective oophorectomy. Menopause, 20(1), 110-114. doi: 10.1097/gme.0b013e31825a27ab

Espejo, E. F., \& Miñano, F. J. (1999). Prefrontocortical dopamine depletion induces antidepressant-like effects in rats and alters the profile of desipramine during Porsolt's test. Neuroscience, 88(2), 609-615. doi: 10.1016/s03064522(98)00258-9

Estrada-Camarena, E., Contreras, C. M., Saavedra, M., Luna-Baltazar, I., \& López-Ruvalcaba, C. (2002). Participation of the lateral septal nuclei (LSN) in the antidepressant-like actions of progesterone in the forced swimming test 
(FST). Behavioural Brain Research, 134(1-2), 175-183. doi: 10.1016/s01664328(02)00023-2

Estrada-Camarena, E., López-Rubalcava, C., Hernández-Aragón, A., MejíaMauries, S., \& Picazo, O. (2011). Long-term ovariectomy modulates the antidepressant-like action of estrogens, but not of antidepressants. Journal of Psychopharmacology, 25(10), 1365-1377. doi: 10.1177/0269881111408456

Etter, A., Cully, D. F., Liu, K. K., Reiss, B., Vassilatis, D. K., Schaeffer, J. M., \& Arena, J. P. (1999). Picrotoxin blockade of invertebrate glutamate-gate chloride channels: Subunit dependence and evidence for binding within the pore. Journal of Neurochemistry, 72(1), 318-326. doi: 10.1111/jnc.1999.72.1.318

Frye, C. A., \& Walf, A. A. (2002). Changes in progesterone metabolites in the hippocampus can modulate open field and forced swim test behavior of proestrous rats. Hormones and Behavior, 4l(3), 306-315. doi: 10.1006/ hbeh.2002.1763

Frye, C. A., \& Walf, A. A. (2004). Hippocampal $3 \alpha, 5 \alpha$-THP may alter depressive behavior of pregnant and lactating rats. Pharmacology, Biochemistry and Behavior, 78(3), 531-540. doi: 10.1016/j.pbb.2004.03.024

Frye, C. A. (2011a). Progesterone reduces depressive behavior of young ovariectomized, aged progestin receptor knockout, and aged wild type mice in the tail suspension test. Journal of Psychopharmacology, 25(3), 421-428. doi: $10.1177 / 0269881109349836$

Frye, C. A. (2011b). Progesterone attenuates depressive behavior of younger and older adult C57/BL6, wildtype, and progesterone receptor knockout mice. Pharmacology, Biochemistry and Behavior, 99(4), 525-531. doi: 10.1016/j. pbb.2011.05.024

Gilad, V. H., Rabey, J. M., Eliyayev, Y., \& Gilad, G. M. (2000). Different effects of acute neonatal stressors and long-term postnatal handling on stressinduced changes in behavior and in ornithine decarboxylase activity of adult rats. Developmental Brain Research, 120(2), 255-259. doi: 10.1016/s01653806(00)00012-2

Gouveia Jr, A., Antunes, G., Maximino, C., \& Morato, S. (2009). The effects of diazepam on the elevated T-maze are dependent on the estrous cycle of rats. Psychology \& Neuroscience, 2(2), 227-233. doi: 10.3922/j.psns.2009.2.016

Griffin, L. D., \& Mellon, S. H. (1999). Selective serotonin reuptake inhibitors directly alter activity of neurosteroidogenic enzymes. Proceedings of the National Academy of Sciences of the United States of America, 96(23), 13512-13517. doi: 10.1073 /pnas. 96.23 .13512

Guidotti, A. \& Costa, E. (1998). Can the antidysphoric and anxiolytic profiles of selective serotonin reuptake inhibitors be related to their ability to increase brain $3 \alpha, 5 \alpha$ - tetrahydroprogesterone (allopregnanolone) availability? Biological Psychiatry, 44(9), 865-873. doi: 10.1016/S0006-3223(98)00070-5

Gunn, B. G., Cunningham, L., Mitchell, S. G., Swinny, J. D., Lambert, J. J., \& Belelli, D. (2015). GABAA receptor-acting neurosteroids: a role in the development and regulation of the stress response. Frontiers in Neuroendocrinology, 36, 28-48. doi: 10.1016/j.yfrne.2014.06.001

Harlow, S. D., Gass, M., Hall, J. E., Lobo, R., Maki, P., Rebar, R. W., ... de Villiers, T. J. STRAW +10 Collaborative Group. (2012). Executive summary of the Stages of Reproductive Aging Workshop+ 10: addressing the unfinished agenda of staging reproductive aging. The Journal of Clinical Endocrinology \& Metabolism, 97(4), 1159-1168. doi: 10.1210/jc.2011-3362

Hasebe, S., Ago, Y., Watabe, Y., Oka, S., Hiramatsu, N., Tanaka, T., ... Matsuda, T. (2017). Anti-anhedonic effect of selective serotonin reuptake inhibitors with affinity for $\sigma 1$ receptor in picrotoxin-treated mice. British Journal of Pharmacology, 174(4), 314-327. doi: 10.1111/bph. 13692

Herbison, A. E., \& Fénelon, V. S. (1995). Estrogen regulation of GABAA receptor subunit mRNA expression in preoptic area and bed nucleus of the stria terminalis of female rat brain. The Journal of Neuroscience, 15(3), 2328-2337. doi: 10.1523/JNEUROSCI.15-03-02328.1995

de Jesús-Burgos, M., Torres-Llenza, V., \& Pérez-Acevedo, N. L. (2012). Activation of amygdalar metabotropic glutamate receptors modulates anxiety, and risk assessment behaviors in ovariectomized estradiol-treated female rats. Pharmacology, Biochemistry and Behavior, 101(3), 369-378. doi: 10.1016/j. pbb.2012.01.016

Kalu, D. N. (1991). The ovariectomized rat model of postmenopausal bone loss. Bone Mineral, 15(3), 175-191. doi: 10.1016/0169-6009(91)90124-I
Kalueff, A. V., \& Tuohimaa, P. (2005). Contrasting grooming phenotypes in three mouse strains markedly different in anxiety and activity (129S1, BALB/c and NMRI). Behavioural Brain Research, 160(1), 1-10. doi: 10.1016/j. bbr.2004.11.010

Kara, N. Z., Stukalin, Y., \& Einat, H. (2018). Revisiting the validity of the mouse forced swim test: Systematic review and meta-analysis of the effects of prototypic antidepressants. Neuroscience \& Biobehavioral Reviews, 84, 1-11. doi: 10.1016/j.neubiorev.2017.11.003

Khisti, R. T., Chopde, C. T., \& Jain, S. P. (2000). Antidepressant-like effect of the neurosteroid $3 \alpha$-hydroxy-5 $\alpha$-pregnan-20-one in mice forced swim test. Pharmacology, Biochemistry and Behavior, 67(1), 137-143. doi: 10.1016/ s0091-3057(00)00300-2

Kimura, F., Nishihara, M., Hiruma, H., \& Funabashi, T. (1991). Naloxone increases the frequency of the electrical activity of luteinizing hormone-releasing hormone pulse generator in long-term ovariectomized rats. Neuroendocrinology, 53(1), 97-102. doi: $10.1159 / 000125704$

Lagunas, N., Calmarza-Font, I., Diz-Chaves, Y., \& García-Segura, L. M. (2010). Long-term ovariectomy enhances anxiety and depressive-like behaviors in mice submitted to chronic unpredictable stress. Hormones and Behavior, 58(5), 786791. doi: 10.1016/j.yhbeh.2010.07.014

Lozano-Hernández, R., Rodríguez-Landa, J. F., Hernández-Figueroa, J. D., Saavedra, M., Ramos-Morales, F. R., \& Cruz-Sánchez, S. (2010). Antidepressant-like effects of two commercially available products of Hypericum perforatum in the forced swim test: A long-term study. Journal of Medicinal Plant Research, 4(2), 131-137.

Maki, P. M., Kornstein, S. G., Joffe, H., Bromberger, J. T., Freeman, E. W., Athappilly, G., ... Soares, C. N. (2019). Guidelines for the Evaluation and Treatment of Preimenopausal Depression: Summary and Recommendations. Journal of Women's Health (Larchmt), 28(2), 117-134. doi: 10.1089/jwh.2018.27099. mensocrec

Martínez-Mota, L., Contreras, C. M., \& Saavedra, M. (1999). Progesterone reduces immobility in rats forced to swim. Archives of Medical Research, 30(4), 286289. doi: 10.1016/S0188-0128(99)00024-X

McGregor, C., Sau, A., Ruddy, S. C., Leung, D., Webb, M., Durst, T., ... Pratt M. C. (2014). Novel ligands balance estrogen receptor $\beta$ and $\alpha$ agonism for safe and effective suppression of vasomotor response in the ovariectomized female rat of menopause. Endocrinology, 155(7), 2480-2491. doi: 10.1210/en.2013-1976

McLaughlin, K. J., Bimonte-Nelson, H., Neisewander, J. L., \& Conrad, C. D. (2008). Assessment of estradiol influence on spatial tasks and hippocampal CA1 spines: Evidence that the duration of hormone deprivation after ovariectomy compromises 17ß-estradiol effectiveness in altering CA1 spines. Hormones and Behavior, 54(3), 386-395. doi: 10.1016/j.yhbeh.2008.04.010

Medina-Maldonado, V., \& Eblen-Zajjur, A. (2018). Effects of estradiol or progesterone on principal cells from amygdala complex evaluation in silico. Revista Mexicana de Neuroeciencias, 19(1), 44-55.

Molina, M., Contreras, C. M., \& Tellez-Alcantara, P. (1999). Mimosa pudica may possess antidepressant actions in the rat. Phytomedicine, 6(5), 319-323. doi: 10.1016/S0944-7113(99)80052-X

Molina-Hernández, M., Tellez-Alcántara, N. P., García, J. P., Lopez, J. O., \& Jaramillo, M. T. (2003). Anti-conflict-like actions of intralateral septal infusions of allopregnanolone in Wistar rats. Pharmacology Biochemistry and Behavior, 75(2), 397-404. doi: 10.1016/S0091-3057(03)00133-3

Muttukrishna, S., Sharma, S., Barlow, D. H., Ledger, W., Groome, N., \& Sathanandan, M. (2002). Serum inhibins, estradiol, progesterone and FSH in surgical menopause: a demonstration of ovarian pituitary feedback loop in women. Human Reproduction, 17(10), 2535-2539. doi: 10.1093/humrep/17.10.2535

National Research Council. (2011). Guide for the Care and Use of Laboratory Animals: Eighth Edition. Washington DC, USA: The National Academies Press. doi: $10.17226 / 12910$

Nestler, E. J., Gould, E., \& Manji, H. (2002). Preclinical models: Status of basic research in depression. Biological Psychiatry, 52(6), 503-528. doi: 10.1016/ S0006-3223(02)01405-1

Nin, M. S., Salles, F. B., Azeredo, L. A., Frazon, A. P. G., Gomez, R., Barros, H. M. T. (2008). Antidepressant effect and changes of GABAA receptor $\gamma 2$ subunit mRNA after hippocampal administration of allopregnanolone in rats. Journal of Psychopharmacology, 22(5), 477-485. doi: 10.1177/0269881107081525 
Norma Oficial Mexicana 062-ZOO-1999. (1999). Especificaciones Técnicas para la Producción, Cuidado y Uso de los Animales de Laboratorio. Secretaría de Agricultura, Ganadería, Desarrollo Rural, Pesca y Alimentación, México City. Available on https://www.gob.mx/cms/uploads/attachment/file/203498/NOM062-ZOO-1999_220801.pdf

Paoletti, A. M., Floris, S., Mannias, M., Orrù, M., Crippa, D., Orlandi, R., ... Melis, G. B. (2001). Evidence that cyproterone acetate improves psychological symptoms and enhances the activity of the dopaminergic system in postmenopause. The Journal of Clinical Endocrinology and Metabolism, 86(2), 608-612. doi: 10.1210/jcem.86.2.7179

Picazo, O., Estrada-Camarena, E., \& Hernández-Aragón, A. (2006). Influence of the post-ovariectomy time frame on the experimental anxiety and the behavioural actions of some anxiolytic agents. European Journal of Pharmacology, 530(12), 88-94. doi: 10.1016/j.ejphar.2005.11.024

Pinna, G. (2010). In a mouse model relevant for post-traumatic stress disorder, selective brain steroidogenic stimulants (SBSS) improve behavioral deficits by normalizing allopregnanolone biosynthesis. Behavioural Pharmacology, 21(56), 438-450. doi: 10.1097/FBP.0b013e32833d8ba0

Pinna, G., Costa, E., \& Guidotti, A. (2006). Fluoxetine and norfluoxetine stereospecifically and selectively increase brain neurosteroid content at doses that are inactive on 5-HT reuptake. Psychopharmacology, 186(3), 362-372. doi: 10.1007/s00213-005-0213-2

Porsolt, R. D., Le Pichon, M., \& Jalfre, M. L. (1977). Depression: A new animal model sensitive to antidepressant treatments. Nature, 266(5604), 730-702. doi: $10.1038 / 266730 \mathrm{a} 0$

Pribilla, I., Takagi, T., Langosch, D., Bormann, J., \& Betz, H. (1992). The atypical M2 segment of $\beta$-subunit confers picrotoxinin resistance to inhibitory glycine receptor channels. The EMBO Journal, 11(12), 4305-4311.

Puga-Olguín, A., Rodríguez-Landa, J. F., Rovirosa-Hernández, M. de J., GermánPonciano, L. J., Caba, M., Meza, E., ... Olmos-Vázquez, O. J. (2019). Long-term ovariectomy increases anxiety-and despair-like behaviors associated with lower Fos immunoreactivity in the lateral septal nucleus in rats. Behavioural Brain Research, 360, 185-195. doi: 10.1016/j.bbr.2018.12.017

Reddy, D. S. (2018). GABA-A receptors mediate tonic inhibition and neurosteroid sensitivity in the brain. Vitamins and Hormones, 107, 177-191. doi: 10.1016/ bs.vh.2017.12.001

Rhodes, M. E., Balestreire, E. M., Czambel, R. K., \& Rubin, R. T. (2002). Estrous cycle influences on sexual diergism of HPA axis responses to cholinergic stimulation in rats. Brain Research Bulletin, 59(3), 217-225. doi: 10.1016/ S0361-9230(02)00868-7

Rodríguez-Landa, J. F., Contreras, C. M., Bernal-Morales, B., Gutiérrez-García, A. G., \& Saavedra, M. (2007). Allopregnanolone reduces immobility in the forced swimming test and increases the firing rate of lateral septal neurons through actions on the GABAA receptor in the rat. Journal of Psychopharmacology, 2l(1), 76-84. doi: 10.1177/0269881106064203

Rodríguez-Landa, J. F., Contreras, C. M., \& García-Ríos, R. I. (2009a). Allopregnanolone microinjected into the lateral septum or dorsal hippocampus reduces immobility in the forced swim test: Participation of the GABAA receptor. Behavioural Pharmacology, 20(7), 614-622. doi: 10.1097/ FBP.0b013e328331b9f2

Rodríguez-Landa, J. F., Cueto-Escobedo, J., Flores-Aguilar, L. Á., Rosas-Sánchez, G. U., Rovirosa-Hernández, M. J., García-Orduña, F., \& Carro-Juárez, M. (2018). The aqueous crude extracts of Montanoa frutescens and Montanoa grandiflora reduce immobility faster than fluoxetine through GABAA receptors in rats forced to swim. Journal of Evidence-Based Integrative Medicine, 23, 2515690X18762953. doi: 10.1177/2515690X18762953

Rodríguez-Landa, J. F., Cueto-Escobedo, J., Puga-Olguín, A., RivadeneyraDomínguez, E., Bernal-Morales, B., Herrera-Huerta, E. V., Santos-Torres, A.
(2017). The phytoestrogen genistein produces similar effects as $17 \beta$-estradiol on anxiety-like behavior in rats at 12 weeks after ovariectomy. BioMed Research International, 2017, 9073816. doi: 10.1155/2017/9073816

Rodríguez-Landa, J. F., García-Ríos, R. I., Cueto-Escobedo, J., Bernal-Morales, B., \& Contreras, C. M. (2013). Participation of GABAA chloride channel in the anxiolytic-like effects of a fatty acid mixture. Biomed Research International, 2013, 121794. doi: 10.1155/2013/121794

Rodríguez-Landa, J. F., Hernández-Figueroa, J. D., Hernández-Calderón, B. C., \& Saavedra, M. (2009b). Anxiolytic-like effect of phytoestrogen genistein in rats with long-term absence of ovarian hormones in the black and white model. Progress in Neuro-Psychopharmacology and Biological Psychiatry, 33(2), 367372. doi: 10.1016/j.pnpbp.2008.12.024

Rodríguez-Landa, J. F., Hernández-López, F., \& Saavedra, M. (2012). Involvement of estrogen receptors in the anxiolytic-like effect of phytoestrogen genistein in rats with 12-week postovariectomy. Pharmacology \& Pharmacy, 3(4), 439-446. doi: $10.4236 / \mathrm{pp} .2012 .34059$

Rodríguez-Landa, J. F., Rodríguez-Santiago, M. G., Rovirosa-Hernández, M., García-Orduña, F., \& Carro-Juárez, M. (2014). Aqueous crude extract of Montanoa tomentosa exerts anxiolytic-like effects in female rats with long-term absence of ovarian hormones. Journal of Chemical, Biological and Physical Sciences, 4(5), 37-46.

Schüle, C., Nothdurfter, C., \& Rupprecht, R (2014). The role of allopregnanolone in depression and anxiety. Progress in Neurobiology, 113, 79-87. doi: 10.1016/j. pneurobio.2013.09.003

Smith, S. S., Waterhouse, B. D., Chapin, J. K., \& Woodward, D. J. (1987). Progesterone alters GABA and glutamate responsiveness: a possible mechanism for its anxiolytic action. Brain Research, 400(2), 353-359. doi: 10.1016/00068993(87)90634-2

Taylor, M. (2001). Psychological consequences of surgical menopause. The Journal of Reproductive Medicine, 46(3 Suppl), 317-324.

Tominaga, K., Yamauchi, A., Shuto, H., Niizeki, M., Makino, K., Oishi, R., \& Kataoka, Y. (2001). Ovariectomy aggravates convulsions and hippocampal gamma-aminobutyric acid inhibition induced by cyclosporin $\mathrm{A}$ in rats. European Journal of Pharmacology, 430(2-3), 243-249. doi: 10.1016/s00142999(01)01377-2

Tonge, S. R., \& Greengrass P. M. (1971). The acute effects of oestrogen and progesterone on the monoamine levels of the brain of ovariectomized rats. Psychopharmacologia, 21(4), 374-381. doi: 10.1007/bf02419060

Uzunov, D. P., Cooper, T. B., Costa, E., \& Guidotti, A. (1996). Fluoxetine-elicited changes in brain neurosteroid content measured by negative ion mass fragmentography. Proceedings of the National Academy of Sciences, 93(22), 12599-12604. doi: 10.1073/pnas.93.22.12599

Uzunova, V., Sheline, Y., Davis, J. M., Rasmusson, A., Uzunov, D. P., Costa, E., \& Guidotti, A. (1998). Increase in the cerebrospinal fluid content of neurosteroids in patients with unipolar major depression who are receiving fluoxetine or fluvoxamine. Proceedings of the National Academy of Sciences, 95(6), 32393244. doi: 10.1073/pnas.95.6.3239

Walf, A. A., Sumida, K., \& Frye, C. A. (2006). Inhibiting 5alpha-reductase in the amygdala attenuates antianxiety and antidepressive behavior of naturally receptive and hormone-primed ovariectomized rats. Psychopharmacology, 186(3), 302-311. doi: 10.1007/s00213-005-0100-x

Wronski, T. J., Dann, L. M., Scott, K. S., \& Cintrón, M. (1989). Long-term effects of ovariectomy and aging on the rat skeleton. Calcified Tissue International, 45(6), 360-366. doi: 10.1007/bf02556007

Zsakai, A., Karkus, Z., Utczas, K., Biri, B., Sievert, L. L., \& Bodzsar, E. B. (2016). Body fatness and endogenous sex hormones in the menopausal transition. Maturitas, 87, 18-26. doi: 10.1016/j.maturitas.2016.02.006 